\title{
Possibilities of using sprouted wheat grain in meat semi-finished products for a healthy diet
}

\author{
E.S. Belokurova ${ }^{1}$, I.A. Pankina ${ }^{1}$, I. Asfondyarova ${ }^{1}$, and B.T. Abdizhapparova ${ }^{2}$ \\ ${ }^{1}$ Peter the Great Saint-Petersburg Polytechnic University, 195251 Polytechnicheskaya, 29, St. \\ Petersburg, Russia \\ ${ }^{2}$ M. Auezov South Kazakhstan State University, Shymkent, Kazakhstan
}

\begin{abstract}
One of the ways to enrich food with essential micronutrients is to use cereals and legumes. The inclusion of wheat germ in the daily diet is the basis of "correct" and "healthy" nutrition systems. One of the most promising ways to create food products with desired properties is the use of a computational method for optimizing the amino acid rate of finished foods. By correctly selecting the component and nutrient composition, it is possible to produce food products for functional, specialized and therapeutic and prophylactic nutrition. Only by using of modern software you can quickly select and adjust the diet for various population groups, taking into account national and regional characteristics. The digitalization of world markets provides prerequisites for the creation of many newest software products that help technologists in the development of recipes for functional and preventive food products, raising food production to a new quality level.
\end{abstract}

\section{Introduction}

Nowadays, issues related to proper nutrition have gone far beyond the medical sciences [1-5]. Food occupies a special place in the life of modern society. Sociologists believe that personal and family experience, the development of the healthy food market, and the expanding production of new food products have a significant impact on the formation of healthy eating habits. It is important that healthy eating has become an integral part of a healthy lifestyle for a modern person in recent years [5]. Russian consumers associate healthy eating not only with the consumption of high-quality, environmentally friendly products. Consuming foods that are balanced in essential nutrients is also considered important. In this regard, great attention should be paid to the latest developments of specialists in the field of production of new combined, fortified food products, balanced in amino acid composition [7-10]. At the same time, in our time, software products related to technologies in the food and trade industry are also acquiring special relevance [11-13].

The modern developments in the field of nutrition are widely used. The latest data are added to the existing digital platforms for personalized human nutrition. Software products for calorie counting and formation of a healthy diet are updated [14]. Therefore, studies devoted to the selection of optimized formulations in terms of component and nutrient composition are relevant. And the introduction of such programs into industrial production 
is even more important. Also, it's necessary to remember about quality and safety of raw materials and food products [15-20].

The food products with specified properties are created based on the principles of combining the chemical composition of the main ingredients that make up the product. These ingredients should form certain sensory, physicochemical, rheological, technological and structural properties of product in order to obtain its specified quality indicators [21].

Modeling of multicomponent multifunctional products using not only food raw materials of plant and animal origin, but also various biologically active additives is the most widespread way to create new food products with desired properties in the $21 \mathrm{st}$ century $[22,23]$.

One of the ways to enrich the food with essential micronutrients is to use cereals and legumes. In the $50 \mathrm{~s}$ of the XX century, germinated wheat took a leading position in world nutrition after numerous studies of the biochemical composition. In many countries wheat germ was included in the daily diet, and it has become the main basis of most systems of "correct", "healthy" nutrition.

In the 21 st century, wheat germ is still very popular. It is an indispensable part of the diets of healthy lifestyle followers and is widely used in recipes for various culinary dishes. The undoubted advantage of using seedlings of grain crops is their availability and low price.

Wheat germs, being an excellent multi-ingredient additive, are often recommended for use in poultry-based combo foods. According to experts, the production of poultry meat in Russia is increasing the recent years. At present, Russian consumers prefer domestic products, which are chilled broiler meat. Shops and public catering enterprises vend poultry and produce many semi-finished and ready-to-eat products based on minced meat.

However, in addition to the currently popular semi-finished products from minced meat, it is advisable to produce combined meat and vegetable minced products. It is preferable to use cereals, legumes, and fruits and vegetables [1] during their production. In this context, wheat germ is of particular interest.

In this work, wheat germ was used to increase the biological value of minced poultry products, namely, to enrich its mineral composition. The purpose of this work was to develop a recipe and technology for food products from raw materials of animal origin, enriched with essential micronutrients.

\section{Materials and methods}

The objects of the study were samples of the culinary product "Chicken Souffle", which we produced using the classical technology (control sample) and with the addition of wheat germ as an enrichment additive (test sample).

When cooking, the chicken fillet was chopped in a household meat grinder and whisked into an airy mass.

Wheat grains were soaked in water and germinated at $18-20{ }^{\circ} \mathrm{C}$ for $4-5$ days until the appearance of 1.5-2.0 cm seedlings. The germinated grains were dried and ground in a household coffee grinder. The ground grains were added to the minced chicken fillet and mixed well until smooth.

The "Chicken Souffle" was steamed. Then, an organoleptic analysis of the obtained culinary products was carried out.

Analytical methods were used to determine the nutritional and biological value. To express the biological value of protein products, one often uses methods based on comparing the results of determining the amino acid composition of proteins of the test product with the "ideal" protein. The amino acid score method is one of the most indicative ones. 
To calculate the amino acid score, the content of each essential amino acid in the test product is compared with its content in the "ideal" protein

$$
A A S=\frac{A A}{A A_{i p}} \times 100
$$

where $A A S$ is the amino acid score, \%; $A A$ is the amino acid content in $1 \mathrm{~g}$ of the meal protein, $\mathrm{mg} ; A A_{i p}$ is the amino acid content in $1 \mathrm{~g}$ of the "ideal" protein, $\mathrm{mg}$.

\section{Results and Discussion}

The nutritional value of chicken fillet and wheat germs was calculated, and it was found that wheat, as a plant product, contains more carbohydrates, and chicken meat contains more proteins. The undoubted advantage of wheat germs is the presence of microelements such as zinc, copper, manganese. Selenium, which has powerful antioxidant properties, is absent in chicken meat, and in wheat germs, its amount is $42.5 \mu \mathrm{g}$ per $100 \mathrm{~g}$.

The quantitative content of essential amino acids is known to be one of the most important indicators of the biologi-cal value of a product $(\mathrm{mg} / 100 \mathrm{~g}$ of product). The quantitative content of amino acids in the control and experimental samples was determined by calculation, the obtained results are shown in Fig. 1.

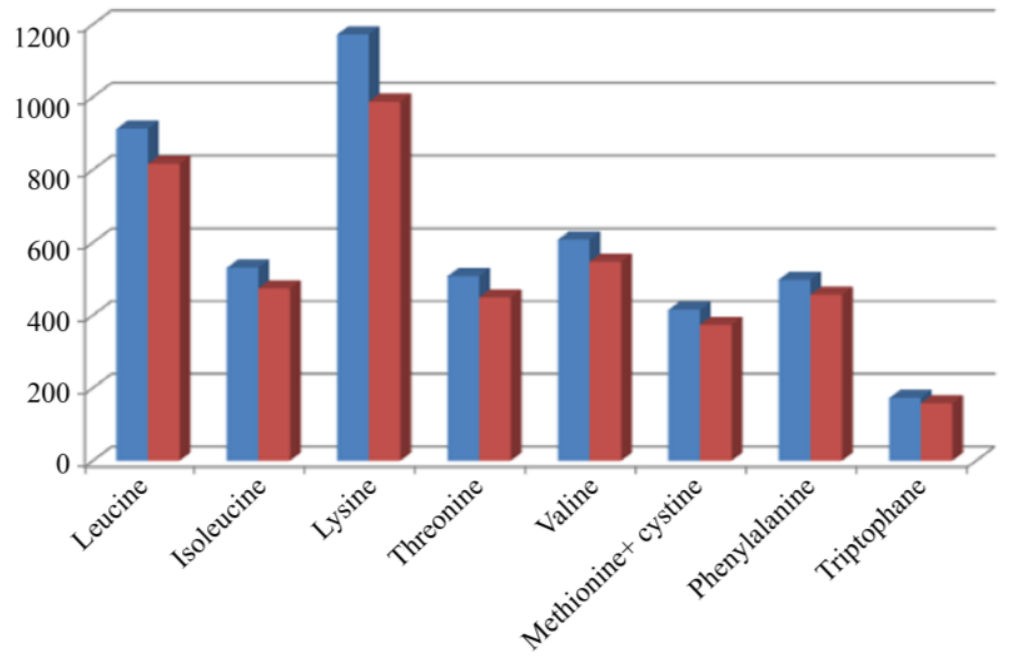

Fig. 1. Comparative content of essential amino acids in the test samples, blue color is used for control sample, red color is used for test sample.

When calculating the amino acid score, the content of each essential amino acid in the test product was compared with that in the "ideal" protein.

The calculated amino acid scores of the control and test samples are presented in Table 1.

Using the norms of daily consumption of the most important nutrients, we calculated their quantitative content in $100 \mathrm{~g}$ in samples of finished culinary products (see Table 2). 
Table 1. The calculated amino acid scores of the samples.

\begin{tabular}{|c|c|c|c|c|c|c|c|}
\hline \multirow{2}{*}{ Amino acid } & \multicolumn{2}{|c|}{ In the meal, mg } & \multicolumn{2}{|c|}{$\begin{array}{l}\text { In } 1 \mathrm{~g} \text { of the meal } \\
\text { protein, } \mathrm{g}\end{array}$} & \multirow{2}{*}{$\begin{array}{l}\text { In } 1 \text { g of } \\
\text { "ideal" } \\
\text { protein }\end{array}$} & \multicolumn{2}{|c|}{$\begin{array}{c}\text { Amino acid score, } \\
\%\end{array}$} \\
\hline & $\begin{array}{l}\text { Control } \\
\text { sample }\end{array}$ & $\begin{array}{l}\text { Test } \\
\text { sample }\end{array}$ & $\begin{array}{l}\text { Control } \\
\text { sample }\end{array}$ & $\begin{array}{c}\text { Test } \\
\text { sample }\end{array}$ & & $\begin{array}{l}\text { Control } \\
\text { sample }\end{array}$ & $\begin{array}{c}\text { Test } \\
\text { sample }\end{array}$ \\
\hline Valine & 608.43 & 547.20 & 52.91 & 52.62 & 50.00 & 105.82 & 105.24 \\
\hline Isoleucine & 530.89 & 473.86 & 46.16 & 45.56 & 40.00 & 115.40 & 113.90 \\
\hline Leucine & 912.84 & 816.32 & 79.38 & 78.49 & 70.00 & 113.40 & 112.13 \\
\hline Lysine & 1172.54 & 987.43 & 101.96 & 94.95 & 55.00 & 185.38 & 172.64 \\
\hline $\begin{array}{l}\text { Methionine+ } \\
\text { cystine }\end{array}$ & 415.16 & 373.78 & 36.10 & 35.94 & 35.00 & 103.14 & 102.69 \\
\hline Threonine & 507.97 & 449.17 & 44.17 & 43.19 & 40.00 & 110.43 & 107.98 \\
\hline Tryptophan & 172.51 & 157.77 & 15.00 & 15.17 & 10.00 & 150.00 & 151.70 \\
\hline Phenylalanine & 498.27 & 456.25 & 43.33 & 43.87 & 60.00 & 72.22 & 73.12 \\
\hline
\end{tabular}

Table 2. The content of mineral substances in the studied meal samples.

\begin{tabular}{|c|c|c|c|c|c|}
\hline & \multicolumn{5}{|c|}{ Microelements content, $\mu \mathrm{g}$ in $100 \mathrm{~g}$ of product } \\
\hline Sample & Iron & Manganese & Copper & Selenium & Zink \\
\hline Control & 842.50 & 39.91 & 53.90 & 0.04 & 652.25 \\
\hline Test & 1008.00 & 36.63 & 83.20 & 14.81 & 779.50 \\
\hline
\end{tabular}

The table shows that the content of selenium, iron, copper, and zinc is significantly higher in the products obtained with the addition of wheat germ. Due to the enriched composition and high iron content, the developed combined meat-vegetable product is recommended for use in the diet of athletes, pregnant and nursing women.

Consequently, the purposeful development of combined food products makes it possible to create recipes for dishes and culinary products with an enriched component composition and desired properties. A correctly selected component and nutrient composition makes it possible to produce food products for functional, specialized and therapeutic and preventive nutrition.

\section{Conclusion}

The digitalization of world markets provides prerequisites for the creation of many newest software products. They are used by technologists for the development of recipes for functional and preventive food products, raising food production to a new quality level.

Only with the help of modern software one can quickly select and adjust the diet for various population groups, taking into account their national and regional characteristics.

One of the most promising ways to create food products with desired properties is to use the computational method for optimizing the amino acid rate of finished food products. This method was used to create a recipe for the combined culinary product "Chicken Souffle" with wheat germ. The developed product was found to have high amino acid score rates for almost all essential amino acids. Lysine, tryptophan, isoleucine, and leucine have high AAS rates, which vary in the range of $185-113 \%$. Phenylalanine is the limiting amino acid.

The developed recipe allows one to get a ready-made enriched product and eliminate the deficiency of such essential micronutrients as iron and selenium.

Thus, modern developments of specialists in the field of nutrition have to be taken into account when modeling new types of multicomponent products for specialized and functional purposes. Such developments together with IT technologies, will significantly 
improve the adjustment of diets for various population groups, taking into account the available raw materials.

Based on the latest research, having a stock of basic and auxiliary raw materials, it is possible to produce high quality finished products with minimal costs, which will be competitive in the world market.

\section{References}

1. Tutelyan V.A., Sukhanov B.P., Kerimova M.G., Elizarova E.V. Optimization of Russians' nutrition is the path to the health and life quality. Sechenovskiy vestnik [Sechenov Bulletin]. 2014; 3 (17): 8-13 (2014).

2. Pogozheva A.V., Baturin A.K. Proper nutrition - is the Foundation of health and longevity. Pishchevaya promyshlennost' [Food Industry]. 2017; (10): 58-61. https://doi.org/10.1088/1757-899X/497/1/012088 (2017).

3. Martinchik A.N., Baturin A.K., Mikhailov N.A., Keshabyants E.E., Kambarov A.O. Development and assessment of the reliability of the basic of healthy eating index in the Russian population. Voprosy pitaniia [Problems of Nutrition]. 2019; 88 (6): 3444.) (2019).

4. On the basis of the Russian Federation's state policy in the fi eld of healthy nutrition for the period up to 2020: Oder of the RF Government of 25.10.2010 number 1873-r. Rossiyskaya gazeta [Russian Newspaper]. 03.11.2010: 19.

5. Bazarnova, J., Eliseeva, S., Zhilinskaya, N., Barsukova, N., Aronova, E., \& Korzh, A. (2020). Metabiotics in molecular nutrition: History and practice. Paper presented at the E3S Web of Conferences, 161 doi:10.1051/e3sconf/202016102005

6. Kaprin A.D., Aleksandrova L.M., Starinsky V.V. Medical and social aspects of the formation of the concept of a healthy lifestyle in Russia. Russkiy meditsinskiy zhurnal [Russian Medical Journal]. 2017; 25 (14): 995-9 (2017).

7. Strategies to improve the quality of food products in the Russian Federation until 2030: Oder of the RF Government of 29.07.2016 number 1364 (2016).

8. Standards $f$ physiological needs for energy and feedstuff $s$ for various groups of the population of the Russian Federation. Metodicheskie rekomendatsii. MR 2.3.1.243208. Moscow: Ministry of Healthcare of the Russian Federation; 2008: 42 p. (2008).

9. Energy and protein requirements: Report of a joint FAO/WHO/ UNU expert consultation. In: WHO Technical Report Series No. 724. Geneva: WHO, (1987).

10. Eliseeva LG, Portnov NM. [Evaluation of the diet based on the variability of the food composition data]. Vopr Pitan. 2020;89(2):77-89. Russian. doi: 10.24411/0042-88332020-10018. (2020)

11. Ianenko M, Ianenko M, Huhlaev D and Martynenko O 2019 Digital transformation of trade: problems and prospects of marketing activities. International Scientific Conference "Digital Transformation on Manufacturing, Infrastructure and Service", 21-22 November 2018, Saint-Petersburg, Russian Federation, DOI: 10.1088/1757$899 X / 497 / 1 / 012118$

12. L. Desfonteines, E. Korchagina, A.Varnaev, J. Semenova. Organizational culture of trade enterprises in the context of modern demographic challenges and applying information technologies. Proceeding of the 2d International Scientific Conference on Digital Transformation on Manufacturing, Infrastructure and Service (DTMIS). IOP Conf. Ser.Mater. Sci. Eng.497(1), 012117 (2019). DOI: 10.1088/1757899X/497/1/012117 (2019). 
13. Matt, C., Hess, T. \& Benlian, A., 2014. Digital Transformation Strategies. Business \& Information Systems Engineering, 57(5), pp.339-343 (2014).

14. Belyakova Z.Y., Makeeva I.A., Stratonova N.V., Pryanichnikova N.S., Bogatyrev A.N., et al. Role of organic products in the implementation of the state policy of healthy nutrition in the Russian Federation. Foods and Raw Materials, 2018, 6 (1): 4 13. DOI:10.21603/2308-4057-2018-1-4-13 (2018).

15. Kamenik, L.: The role of data management in resource recycling. In: Proceedings of the 33rd International Business Information Management Association Conference, IBIMA 2019: Education Excellence and Innovation Management through Vision 2020. pp. 8562-8567 (2019).

16. Korshunov, G.I., Petrushevskaya, A.A.: Modeling of digital manufacturing of electronics production and product quality assurance. In: CEUR Workshop Proceedings. pp. 150-159 (2018).

17. Asfondiarova, I., Demchenko, V., Illarionova, K., Kravtsova, E.: Digital technologies for providing the quality of food products. In: IOP Conference Series: Materials Science and Engineering (2019). doi.org/10.1088/1757-899X/497/1/012106 (2019).

18. Grebenikova N., Davydov V., Moroz F., Bylina M., Kuzmin M. Remote control of the quality and safety of the production of liquid products with using fiber-optic communication lines of the internet. The second international scientific conference "Digital transformation on manufacturing, infrastructure and service". 2019; SaintPetersburg, 2019. pp. 012109. DOI: 10.1088/1757-899X/497/1/012109 (2019)

19. Pankina I.A., Belokurova E.S., Politaeva N.A., Lomasov V.N., Bashun N.Z. Modern methods of treatment plant materials for waste minimization. 2019 International scientific conference on energy, environmental and construction engineering, EECE 2019. DOI: 10.1051/e3sconf/201914002014 (2019)

20. Smyatskay Y., Pankina I., Kulikova L., Sobgaida D. Nitrate content in vegetables and fruits in Russia and Mongolia. E3S Web of Conferences. International Conference on Efficient Production and Processing, ICEPP 2020. 2020.p. 01066. DOI: 10.1051/e3sconf/202016101066 (2020)

21. Pleskacheva M., Artamonova M., Litvinova E., Gergel M., Davydova E. Methodology for identification and quantification of chicken meat in food products. Foods and Raw Materials. 2020;8(1):98-106. DOI: 10.21603/2308-4057-2020-1-98-106 (2020).

22. Lisitsyn A., Chernukha I., Nikitina M. Russian methodology for designing multicomponent foods in retrospect. Foods and Raw Materials. 2020;8(1):2-11. DOI: 10.21603 / 2308-4057-2020-1-2-11 (2020).

23. Aret V.A. Use of food resources and development of food production technology. Foods and Raw Materials, 2017, 5 (1): 4-10. DOI: 10.21179/2308-4057-2017-1-4-10 (2017). 